\title{
Applying Tire Rubber Ash Enriched Cow Manure as a Useful Way to Decrease Canola Cd Uptake in a Polluted Soil
}

\author{
Amir Hossein Baghaie ${ }^{1,}{ }^{,}$, Forough Aghili ${ }^{2}$ and Ali Hassani Joshaghani ${ }^{3}$ \\ ${ }^{1}$ Department of Soil Science, Arak Branch, Islamic Azad University, Arak, Iran \\ ${ }^{2}$ Young Researchers and Elite Club, Arak Branch, Islamic Azad University, Arak, Iran \\ ${ }^{3}$ Department of Chemical Engineering, Arak Branch, Islamic Azad University, Arak, Iran \\ "Corresponding author: Department of Soil Science, Arak Branch, Islamic Azad University, Arak, Iran. Email: a-baghaie@iau-arak.ac.ir
}

Received 2018 July 25; Revised 2018 September 12; Accepted 2018 October 27.

\begin{abstract}
Background: Cadmium (Cd) is a toxic heavy metal that affects plant growth and human health. Therefore, it is necessary to reduce its concentration.

Objectives: This research was done to investigate the role of tire rubber ash enriched cow manure application to reduce Cd uptake by canola.

Methods: Treatments were consist of applying three levels of cow manure $\left(0,10\right.$ and $\left.20 \mathrm{t} \mathrm{ha}^{-1}\right)$, two levels of tire rubber ash (0 and $\left.200 \mathrm{~kg} \mathrm{ha}^{-1}\right)$ in a Cd polluted soil $\left(0,5,10\right.$ and $\left.15 \mathrm{mg} \mathrm{Cd}(\mathrm{kg} \text { soil })^{-1}\right)$. The $\mathrm{Cd}$ and Zinc $(\mathrm{Zn})$ concentration of canola was measured using atomic absorption spectroscopy. This research was done as a factorial experiment in the layout of completely randomized block design with three replications.

Results: Applying 20 t ha $^{-1}$ tire rubber ash enriched cow manure in $10 \mathrm{mg} \mathrm{Cd}(\mathrm{kg} \text { soil })^{-1}$ polluted soils decreased root Cd concentration by $30.1 \%$, while the root $\mathrm{Zn}$ concentration was increased by $17 \%$. In addition, applying the above amount of organic amendment in $15 \mathrm{mg} \mathrm{Cd}(\mathrm{kg} \text { soil })^{-1}$ polluted soils decreased grain Cd concentration by $45.7 \%$, while the grain Zn concentration was increased by $27 \%$. In addition, the aboveground biomass of plant was also increased by $30 \%$.

Conclusions: The results of this study showed that enrichment of cow manure with tire rubber ash can decrease plant Cd concentration in Cd polluted soils (interaction effects of $\mathrm{Cd}$ and $\mathrm{Zn}$ ), that is a positive point in environmental research. However, the type of plant and amount of pollution could not be ignored.
\end{abstract}

Keywords: Environmental Pollution, Rubber, Cadmium, Zinc, Manure

\section{Background}

Cadmium (Cd) is a highly toxic element with no positive physiological function for plants and humans (1). Cd is accumulated in different plant organs (2) and can be consumed if these plants are used as food. Excessive intake of Cd leads to serious medical problems such as itai-itai disease, lung cancer, gastrointestinal cancer, kidney damage, and liver disease (3). Therefore, it is necessary to either clean Cd from soil or control its uptake by plants to enhance the environmental quality and human health (4). To achieve these aims, different methods such as soil washing, excavation, and land filling have been developed (5). However, due to high costs and difficulties in removing toxic metals from soil and water by conventional methods, research is presently focused on low-cost as well as easy and safe technologies (6).

Cd and Zinc (Zn) have similar geochemical and environmental properties, which causes an antagonistic inter- action between them during plant uptake, transport from roots to the aerial parts, or accumulation in edible parts of plants (7-9). On the other hand, it has well known that $\mathrm{Zn}$ is not only an essential micronutrient for humans and animals (10), however, it also supports growth and yields the quality of plants (11).

It has been reported that some agricultural lands in Iran are contaminated with $\mathrm{Cd}$ due to industrial activities, high application of low-quality phosphate-fertilizers containing Cd as impurities, and geological properties (12). Additionally, plant available $\mathrm{Zn}$ in soils of central part of Iran such as Arak is low (13), and use efficiency of Zn fertilizers in soils is limited due to natural soil physic-chemical properties (14). Application of organic matter, such as cow manure, is an important strategy to enhancing micronutrient bioavailability and improving use efficiency of different kinds of micronutrient fertilizers in low organic matter soils such as soils of the central part of Iran. 
Canola (Okapi Cv.) is cultivated in central parts of Iran periodicity with wheat and is consequently recommended by the Markazi Agricultural and Natural Resource Research Centre to cultivate in Markazi province due to its adaptation to climatic conditions of this area. However, canola is a high sensitive plant to $Z n$ deficiency.

Tire rubber is a good source of $\mathrm{Zn}$, it contains of approximately $1 \%-2 \%$ of $\mathrm{Zn}(15)$, and could be a profit fertilizer especially in an area with low soil Zn bioavailability such as Iran (16). In a study by Taheri et al., the amount of Zn increased significantly when calcareous Zn-deficient soil was amended with tire rubber ash (16). On the other hand, Baghaie showed that applying $40 \mathrm{tha}^{-1}$ tire rubber ash enriched municipal waste compost significantly decrease the spinach Cd concentration (17). According to Khoshgoftarmanesh et al. (18), applying tire rubber ash is an important way to reduce plant $\mathrm{Cd}$ concentration due to the completive effect of $\mathrm{Cd}$ and $\mathrm{Zn}$.

\section{Objectives}

This study was done to investigate the influence of tire rubber ash enriched cow manure on Cd bioavailability in soil and canola $\mathrm{Cd}$ concentration in a Zn deficient soil that is polluted with $\mathrm{Cd}$.

\section{Methods}

\subsection{Study Design}

A factorial experiment with a randomized complete block design in three replications was done in the greenhouse. The factors were zero $\left(\mathrm{C}_{0}\right), 10\left(\mathrm{C}_{10}\right)$, and $20\left(\mathrm{C}_{20}\right) \mathrm{t}$ ha $^{-1}$ cow manure, $0\left(\mathrm{~T}_{0}\right)$ and $200\left(\mathrm{~T}_{200}\right) \mathrm{kg} \mathrm{ha}^{-1}$ tire rubber ash, and zero $\left(\mathrm{Cd}_{0}\right)$, five $\left(\mathrm{Cd}_{5}\right), 10\left(\mathrm{Cd}_{10}\right)$, and $15\left(\mathrm{Cd}_{15}\right) \mathrm{mg} \mathrm{Cd}$ $(\mathrm{kg} \text { soil })^{-1}$.

\subsection{Soil Origin and Physicochemical Properties}

The soil used for this experiment was Typic Haplocambid (19) collected from the top $30 \mathrm{~cm}$ soil layer of a field at Pakal village, located $30 \mathrm{~km}$ west of Arak. The soil texture was a silty clay loam based on the hydrometer method (20). The $\mathrm{pH}$ was 7.1 and the electrical conductivity (EC) was 0.84 $\mathrm{dSm}^{-1}$. The soil organic C was $0.17 \%$, based on the Walkley and Black methods (21). The cation exchangeable capacity (CEC) was $11 \mathrm{Cmol}^{(+)}\left(\mathrm{kg} \mathrm{soil}^{-1}\right.$ as determined by the Rhoads (22). The DPTA extractable $\mathrm{Cd}$ and $\mathrm{Zn}$ was analyzed using the Lindsay method (23). The amount of DTPA-extractable $\mathrm{Zn}$ was $0.12 \mathrm{mg}(\mathrm{kg} \text { soil })^{-1}$. The DTPA-extractable $\mathrm{Cd}$ was not detectable by atomic absorption spectroscopy (AAS).

\subsection{Preparation of Tire Rubber Ash}

Experimental tire rubber was prepared from the rubber industry of Yazd tire in Iran and then ashed in a furnace at $550^{\circ} \mathrm{C}$ for 12 hours. The total concentration of $\mathrm{Zn}, \mathrm{Fe}, \mathrm{Cd}$, and $\mathrm{Pb}$ of the tire rubber ash were 10840, 83.4, 7.96, and $0.94 \mathrm{mg}(\mathrm{kg} \mathrm{DW})^{-1}$, respectively, according to energy dispersive X-ray fluorescence spectrometry (XRF) on a Spectra X-Lab 2000 instrument (SPECTRO Analytical Instruments $\mathrm{GmbH}$, Kleve, Germany).

\subsection{Cow Manure Chemical Analysis}

The total concentration of $\mathrm{Zn}, \mathrm{Cd}$, and $\mathrm{Pb}$ in the cow manure were 98.32, 0.61, and $0.73 \mathrm{mg}(\mathrm{kg} \mathrm{DW})^{-1}$, respectively. The organic $\mathrm{C}$ of cow manure was $18.12 \%$ and the CEC was $9.33 \mathrm{Cmol}^{(+)}(\mathrm{kg} \mathrm{soil})^{-1}$. The $\mathrm{pH}$ of cow manure was 7.22. The total $\mathrm{N}$ of samples was $1.3 \%$, according to the Kjeldahl method (24).

\subsection{Soil Preparation}

To have tire rubber ash enriched cow manure, different levels of cow manure were enriched by different levels of tire rubber ash and incubated for three months in a room with a temperature of $25^{\circ} \mathrm{C}$. Then, four levels of $\mathrm{Cd}$ in the form of $\mathrm{CdNO}_{3}$ were sprayed in the soil samples and incubated in a room for three months. After incubation time, the tire rubber ash enriched cow manure were added to the Cd treated soils and mixed roughly to assure its homogeneous distribution.

\subsection{Growth Conditions and Mineral Nutrient Analyses}

Canola seedling were first surface sterilized in $15 \% \mathrm{H}_{2} \mathrm{O}_{2}$ thoroughly washed in distilled water, and pre-germinated on moistened filter paper. After that, two canola seedlings were planted into each pot with five kg soil. At harvest, aboveground parts and the roots of plants were washed and dried at $75^{\circ} \mathrm{C}$ for 72 hours and weighted.

For chemical analyses, the milled samples were incinerated at $550^{\circ} \mathrm{C}$ for six h, dissolved in one $\mathrm{ml}$ of $13 \mathrm{M} \mathrm{HNO}_{3}$ and heated in $220^{\circ} \mathrm{C}$ for one minute (25). The concentrations of $\mathrm{Cd}$ and $\mathrm{Zn}$ were determined by AAS ( 800 model). The accuracies of $\mathrm{Cd}$ and $\mathrm{Zn}$ analyses were controlled by analyzing certified standard materials. Soil $\mathrm{pH}, \mathrm{CEC}$, total $\mathrm{N}$ content, and DTPA-extractable $\mathrm{Cd}$ and $\mathrm{Zn}$ were measured at the end of the experiment, using the above-described analytical procedures.

\subsection{Plant Growth Factor Index}

To determine the ability of canola to grow in different research treatments, the plant growth factor index (GI) was calculated as below (26):

GI $(\%)=($ DW of treated plants $) /(\mathrm{DW}$ of control plants $)$ $\times 100(1)$

Where DW is the dry weight of canola aboveground biomass. 


\section{Results}

\subsection{Soil Chemical Properties}

Soil $\mathrm{pH}$ was not affected by any of the treatments (data not shown). Cow manure addition significantly increased CEC and total soil N, irrespectively from the tire rubber ash and $\mathrm{Cd}$ concentration (Figure $1 \mathrm{~A}$ and $\mathrm{B}$ ). The total $\mathrm{N}$ content in soils treated with cow manure was significantly ( $P$ $<0.05$ ( higher than in those that did not (Figure 1B).

The concentration of soil DTPA-extractable Cd was significantly higher in the treatments without tire rubber ash enriched cow manure than with it (Table 1). The highest concentration of plant available Cd in soil ( $\left.6.3 \mathrm{mg} \mathrm{kg} \mathrm{DM}^{-1}\right)$ was observed in soils treated with the highest level of Cd but amended with neither tire rubber ash nor with cow manure (Table1). The concentration of DTPA-extractable Zn in soils was significantly higher in the treatments with tire rubber ash enriched cow manure than without it. Increasing the Cd concentration of soil significantly reduced soil DTPA-extractable Zn concentration (Table 1).

\subsection{Plants Biomass}

The aboveground biomass of canola was significantly affected by all of the treatments (Table 2). The highest biomass (5.80 g pot $^{-1}$ ) was observed for plants grown in soil without addition of Cd ( 0 Cd level), however, was amended with cow manure and tire rubber ash (Table 2). The lowest aboveground biomass ( $3.50 \mathrm{~g} \mathrm{pot}^{-1}$ ) was recorded for plants grown in soils with addition of $15 \mathrm{mg} \mathrm{Cd}(\mathrm{kg} \text { soil })^{-1}$, however, without cow manure or tire rubber ash (Table 2).

\subsection{Plant Growth Index}

The highest value of GI was observed in plants grown on non-Cd treated soil with the highest ratio of cow manure and tire rubber ash (Table 3). The GI of canola plants was significantly reduced when the level of $\mathrm{Cd}$ in soil increased. Application of cow manure and tire rubber ash to the soil reduced the negative effect of Cd on plant GI (Table 3). The highest levels of cow manure and tire rubber ash in

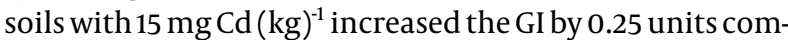
pared to GI of canola plants grown in soils with the same concentration of Cd but without cow manure and tire rubber ash (Table 3).

\subsection{Accumulation of Cd and Zn in Canola Plants}

Grain Cd concentration significantly $(P<0.05)$ decreased with application of cow manure and tire rubber ash (Table 4), whereas the Zn concentration significantly $(\mathrm{P}<0.05)$ increased (Table 4$)$. Regardless of non-Cd polluted soil, the lowest grain Cd concentration $(0.9 \mathrm{mg}(\mathrm{kg}$ $\mathrm{DW})^{-1}$ ) was recorded for plants grown at the lowest application rate of $\mathrm{Cd}\left(5 \mathrm{mg}(\mathrm{kg} \text { soil })^{-1}\right)$ with receiving the highest amount of cow manure and tire rubber ash. The highest grain Zn concentration (11.6 mg $\left(\mathrm{kg} \mathrm{DW}^{-1}\right)$ was observed for plants grown in the absence of Cd but in the presence of cow manure and tire rubber ash (Table 4).

Regardless of non-Cd polluted soil, the lowest Cd concentration in plants roots $\left(7.2 \mathrm{mg}\left(\mathrm{kg} \mathrm{DW}^{-1}\right)\right)$ was observed when the soils amended with the highest amount of cow manure and tire rubber ash, while the root $\mathrm{Zn}$ concentration was increased (Table 4).

The Cd concentration in shoots and grains were significantly correlated with the application rate of cow manure, tire rubber ash, and $\mathrm{Cd}$, according to the models below:

Grain Cd concentration $=6.03-0.20 \mathrm{~V}_{\mathrm{i}}-0.006 \mathrm{~T}_{\mathrm{j}}+0.16$ $\mathrm{Cd}_{\mathrm{k}}, \mathrm{R}^{2}=0.83$

Shoot Cd concentration $=9.32-0.14 \mathrm{~V}_{\mathrm{i}}-0.006 \mathrm{~T}_{\mathrm{j}}+0.31$ $\mathrm{Cd}_{\mathrm{k}}, \mathrm{R}^{2}=0.94$

where, $V_{i}$ is cow manure levels, $T_{j}$ is tire rubber ash levels, and $\mathrm{Cd}_{\mathrm{j}}$ or $\mathrm{Cd}_{\mathrm{k}}$ is soil cadmium concentration.

\section{Discussion}

\subsection{Cd and Zn Availability in Soil}

Addition of Cd to soils without receiving cow manure and tire rubber ash reduced the DTPA-extractable $\mathrm{Zn}$ from 0.12 to $0.01 \mathrm{mg}\left(\mathrm{kg} \mathrm{soil}^{-1}\right)$, which suggest that $\mathrm{Zn}$ and $\mathrm{Cd}$ may compete with each other for sites available for sorption on soil colloids (17). Cd and $\mathrm{Pb}$ have similar chemical and geological properties (27), which may predispose them to behave as competitors for sorption sites (soil phase) or uptake (plant phase). In this way, other authors also have reported that in Cd contaminated soils, the bioavailability of $\mathrm{Zn}$ is low (28).

Application of tire rubber ash enriched cow manure increased the DTPA-extractable Zn concentration (up to 0.49 $\mathrm{mg}$ (kg soil ${ }^{-1}$ ), Table 1 ). Elevated root and microbial exudation in response to addition of cow manure to soil may be a reason of higher DTPA-extractable $\mathrm{Zn}$ concentrations in soil (25). In addition, the role of organic amendments such as cow manure on decresing Cd concentration cannot be ignored. Baghaie reported that applying manucipal waste compost increase soil organic matter that may increase the soil sorption site and thereby deecrease soil Cd concentration (20). The research of Tabarteh et el. (2017) confirm this matter clearly (29).

\subsection{Growth, Cd and Zn Concentration, GI of Canola Plants}

Application of tire rubber ash enriched cow manure increased plants biomass (Table 1). It could be due to plantrelated processes, e.g. improved $\mathrm{N}$ and $\mathrm{C}$ nutrition in the presence of the cow manure, and/or to microorganismsrelated processes, e.g. mobilization of nutrients by rootassociated microbes. In contrast, plants biomass was significantly reduced when concentration of Cd increased (Table 1), which stays in agreement with previously published 
A

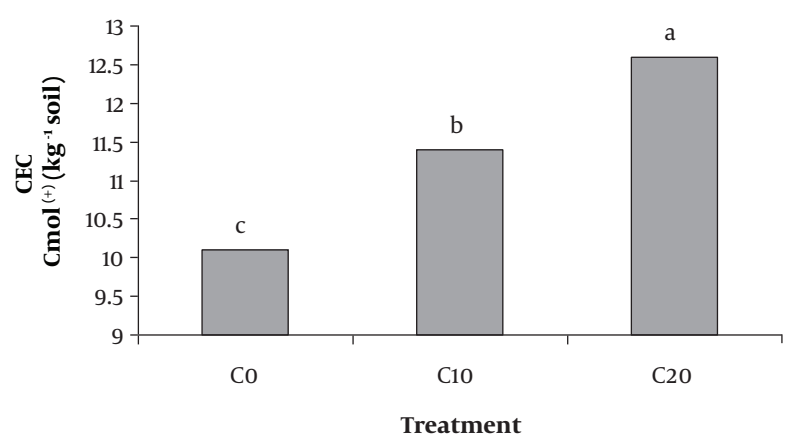

B

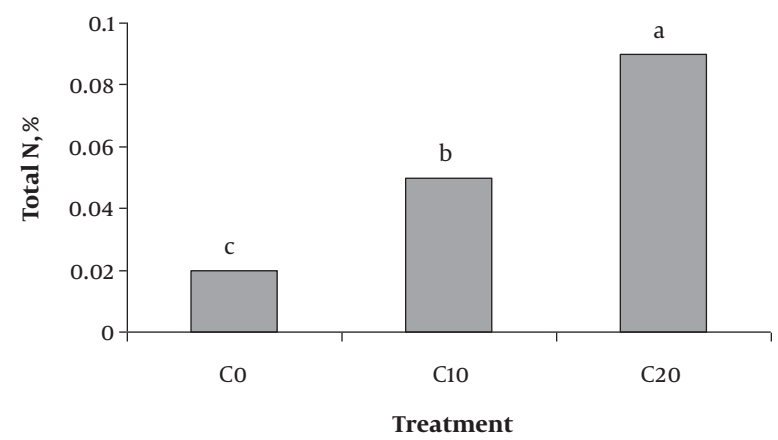

Figure 1. Effect of cow manure on A, CEC; and B, total soil N in soil

Table 1. Effects of Cow Manure Application Rate(C), Tire Rubber Ash Addition(T), and Soil Cadmium Concentration (Cd) on Available Cd and Zn-DTPA Extractable Concentration in Soil $\left(\mathrm{mg}(\mathrm{kg} \mathrm{soil})^{-1}\right)^{\mathrm{a}}$

\begin{tabular}{|c|c|c|c|c|c|c|c|c|c|c|c|c|c|c|c|c|}
\hline \multirow[t]{2}{*}{ Treatment } & \multicolumn{2}{|c|}{$\mathrm{T}_{200} \mathrm{Cd}_{15}$} & \multicolumn{2}{|c|}{$\mathrm{T}_{200} \mathrm{Cd}_{10}$} & \multicolumn{2}{|c|}{$\mathrm{T}_{200} \mathrm{Cd}_{5}$} & \multicolumn{2}{|c|}{$\mathrm{T}_{200} \mathrm{Cd}_{0}$} & \multicolumn{2}{|c|}{$\mathrm{T}_{\mathbf{0}} \mathrm{Cd}_{15}$} & \multicolumn{2}{|c|}{$\mathrm{T}_{0} \mathrm{Cd}_{10}$} & \multicolumn{2}{|c|}{$\mathrm{T}_{0} \mathrm{Cd}_{5}$} & \multicolumn{2}{|c|}{$\mathrm{T}_{\mathbf{0}} \mathrm{Cd}_{\mathbf{0}}$} \\
\hline & Cd & Zn & Cd & Zn & Cd & Zn & Cd & Zn & Cd & Zn & Cd & Zn & Cd & Zn & Cd & Zn \\
\hline$c_{0}$ & $5.6^{\mathrm{b}}$ & $0.06^{\operatorname{lm}}$ & $3.7^{\mathrm{de}}$ & $0.12^{\mathrm{jk}}$ & $2.6^{\mathrm{hi}}$ & $0.19^{g h}$ & ND & $0.28^{\mathrm{de}}$ & $6.3^{\mathrm{a}}$ & $0.01^{\mathrm{n}}$ & $4.5^{\mathrm{c}}$ & $0.04^{\mathrm{mn}}$ & $3.4^{\mathrm{ef}}$ & $0.08^{\mathrm{klm}}$ & ND & $0.12^{\mathrm{jk}}$ \\
\hline$C_{10}$ & $4.9^{c}$ & $0.10^{\mathrm{jkl}}$ & $3.1^{\mathrm{fg}}$ & $0.18^{\mathrm{gh}} \mathrm{i}$ & $2.1^{\mathrm{j}}$ & $0.25^{\mathrm{ef}}$ & ND & $0.38^{\mathrm{b}}$ & $5.6^{\mathrm{b}}$ & $0.07^{\mathrm{lm}}$ & $3.7^{\mathrm{de}}$ & $0.09^{\mathrm{kl}}$ & $2.7^{\mathrm{gh}}$ & $0.14^{\mathrm{ij}}$ & ND & $0.21^{\text {fgh }}$ \\
\hline$C_{20}$ & $3.9^{\mathrm{d}}$ & $0.14^{\mathrm{ij}}$ & $1.5^{\mathrm{k}}$ & $0.22^{\mathrm{fg}}$ & $0.2^{\mathrm{m}}$ & $0.31^{\mathrm{cd}}$ & ND & $0.49^{\mathrm{a}}$ & $4.6^{\mathrm{c}}$ & $0.12^{\mathrm{jk}}$ & $2.2^{\mathrm{ij}}$ & $0.17^{\mathrm{hi}}$ & $0.9^{1}$ & $0.24^{\mathrm{ef}}$ & ND & $0.35^{\mathrm{bc}}$ \\
\hline
\end{tabular}

Abbreviation: ND: Not detectable by atomic absorption spectrophotometer (AAS).

${ }^{\mathrm{a}}$ Different lowercase letters indicate statistically significant differences between treatments. $(\mathrm{P} \leq 0.05$, LSD test).

\begin{tabular}{|c|c|c|c|c|c|c|c|c|}
\hline Treatment & $\mathrm{T}_{200} \mathrm{Cd}_{15}$ & $\mathrm{~T}_{200} \mathrm{Cd}_{10}$ & $\mathrm{~T}_{200} \mathrm{Cd}_{5}$ & $\mathbf{T}_{200} \mathrm{Cd}_{0}$ & $\mathbf{T}_{\mathbf{0}} \mathbf{C d}_{15}$ & $\mathrm{~T}_{\mathbf{0}} \mathrm{Cd}_{10}$ & $\mathbf{T}_{\mathbf{0}} \mathbf{C d}_{5}$ & $\mathbf{T}_{\mathbf{0}} \mathrm{Cd}_{\mathbf{0}}$ \\
\hline $\mathrm{C}_{\mathrm{o}}$ & $3.9^{\mathrm{n}}$ & $4.4^{\mathrm{jk}}$ & $4.7^{\mathrm{gh}}$ & $5.2^{\mathrm{de}}$ & $3.5^{\circ}$ & $4.1^{\mathrm{m}}$ & $4.3^{\mathrm{kl}}$ & $4.6^{\text {hi }}$ \\
\hline$C_{10}$ & $4.5^{\mathrm{ij}}$ & $4.7^{\mathrm{gh}}$ & $5.1^{\mathrm{e}}$ & $5.4^{\mathrm{c}}$ & $4.1^{\mathrm{m}}$ & $4.3^{\mathrm{kl}}$ & $4.8^{\mathrm{fg}}$ & $5.1^{\mathrm{e}}$ \\
\hline$C_{20}$ & $5.1^{\mathrm{e}}$ & $5.3^{c}$ & $5.6^{\mathrm{b}}$ & $5.8^{\mathrm{a}}$ & $4.9^{\mathrm{f}}$ & $5.1^{\mathrm{e}}$ & $5.3^{c}$ & $5.5^{\mathrm{bc}}$ \\
\hline
\end{tabular}

${ }^{\mathrm{a}}$ Different lowercase indicate statistically significant differences between treatments. ( $\mathrm{P} \leq 0.05$, LSD test).

\begin{tabular}{|c|c|c|c|c|c|c|c|c|}
\hline \multirow[t]{2}{*}{ Treatment } & \multicolumn{2}{|c|}{$\mathrm{Cd}_{\mathbf{0}}$} & \multicolumn{2}{|c|}{$\mathrm{Cd}_{5}$} & \multicolumn{2}{|c|}{$\mathrm{Cd}_{10}$} & \multicolumn{2}{|c|}{$\mathrm{Cd}_{15}$} \\
\hline & $\mathbf{T}_{0}$ & $\mathbf{T}_{\mathbf{2 0 0}}$ & $T_{0}$ & $T_{200}$ & $T_{0}$ & $T_{200}$ & $T_{0}$ & $\mathbf{T}_{200}$ \\
\hline $\mathrm{C}_{0}$ & $1.00^{\mathrm{gh}}$ & $1.10^{\mathrm{de}}$ & $0.91^{\mathrm{kl}}$ & $1.00^{\mathrm{gh}}$ & $0.87^{\mathrm{m}}$ & $0.94^{\mathrm{jk}}$ & $0.76^{\circ}$ & $0.84^{\mathrm{n}}$ \\
\hline$C_{10}$ & $1.08^{\mathrm{e}}$ & $1.15^{\mathrm{c}}$ & $1.02^{\mathrm{fg}}$ & $1.08^{\mathrm{e}}$ & $0.91^{1}$ & $1.00^{\mathrm{gh}}$ & $0.87^{\mathrm{m}}$ & $0.95^{\mathrm{ij}}$ \\
\hline$C_{20}$ & $1.18^{\mathrm{b}}$ & $1.34^{\mathrm{a}}$ & $1.14^{\mathrm{c}}$ & $1.19^{\mathrm{b}}$ & $1.08^{\mathrm{e}}$ & $1.12^{\mathrm{cd}}$ & $1.04^{\mathrm{f}}$ & $1.09^{\mathrm{e}}$ \\
\hline
\end{tabular}

${ }^{\mathrm{a}}$ Different lowercase letters indicate statistically significant differences between treatments $(\mathrm{P} \leq 0.05$, LSD test).

research. For example, it has been reported that high concentration of Cd prevents the normal uptake, translocation and usage of mineral nutrients, and leads to reduction in plant growth and development $(30,31)$.

Addition of tire rubber ash enriched cow manure to $\mathrm{Cd}$ polluted soil (15 mg ( $\mathrm{kg}$ soil $\left.)^{-1}\right)$ and reduced Cd concentration of canola significantly (Table 4), which may be due to enhanced uptake of Zn. However, this Cd concentration is still greater than the standard value for plants (32).

A higher concentration of $\mathrm{Zn}$ in grains of plants grown in the presence of tire rubber ash enriched cow manure may imply synergistic effect of these two compounds on uptake of $\mathrm{Zn}$. We assume that as tire rubber ash is served as a direct source of $\mathrm{Zn}$, cow manure probably facilitated 


\begin{tabular}{|c|c|c|c|c|c|c|c|c|c|c|c|c|c|c|c|c|}
\hline \multirow[t]{2}{*}{ Treatment } & \multicolumn{2}{|c|}{$\mathrm{T}_{200} \mathrm{Cd}_{15}$} & \multicolumn{2}{|c|}{$\mathrm{T}_{200} \mathrm{Cd}_{10}$} & \multicolumn{2}{|c|}{$\mathrm{T}_{200} \mathrm{Cd}_{5}$} & \multicolumn{2}{|c|}{$\mathrm{T}_{200} \mathrm{Cd}_{\mathbf{O}}$} & \multicolumn{2}{|c|}{$\mathrm{T}_{0} \mathrm{Cd}_{15}$} & \multicolumn{2}{|c|}{$\mathrm{T}_{\mathbf{0}} \mathrm{Cd}_{10}$} & \multicolumn{2}{|c|}{$\mathrm{T}_{\mathbf{0}} \mathrm{Cd}_{5}$} & \multicolumn{2}{|c|}{$\mathbf{T}_{\mathbf{0}} \mathrm{Cd}_{\mathbf{O}}$} \\
\hline & Cd & Zn & Cd & $\mathrm{Zn}$ & Cd & $\mathrm{Zn}$ & Cd & $\mathrm{Zn}$ & Cd & Zn & Cd & $\mathrm{Zn}$ & Cd & Zn & Cd & $\mathrm{Zn}$ \\
\hline \multicolumn{17}{|c|}{$\begin{array}{l}\text { Grain } \mathrm{Zn} \text { and Cd } \\
\text { concentration }(\mathrm{mg}(\mathrm{kg} \\
\left.\mathrm{DWl})^{-1}\right)\end{array}$} \\
\hline $\mathrm{C}_{0}$ & $9.4^{c}$ & $5.1^{\mathrm{op}}$ & $5.3^{\mathrm{f}}$ & $5.8^{\mathrm{mn}}$ & $2.7^{\mathrm{jk}}$ & $6.4^{\mathrm{klm}}$ & ND & $7.2^{\mathrm{ij}}$ & $12.2^{\mathrm{a}}$ & $3.6^{q}$ & $6.1^{\mathrm{e}}$ & ${ }_{4.5} \mathrm{P}$ & $3.1^{\mathrm{i}}$ & $5.4^{\mathrm{no}}$ & ND & $6.8^{\mathrm{jk}}$ \\
\hline$C_{10}$ & $7.8^{\mathrm{d}}$ & $6.9^{j \mathrm{k}}$ & $3.7^{\mathrm{h}}$ & $7.8^{\mathrm{hi}}$ & $1.9^{1}$ & $8.9^{\mathrm{fg}}$ & $\mathrm{ND}$ & $9.6^{\mathrm{de}}$ & $10.1^{b}$ & $5.9^{1 \mathrm{mn}}$ & $4.8^{\mathrm{g}}$ & $6.5^{\mathrm{kl}}$ & $2.4^{\mathrm{k}}$ & $3.7^{9}$ & ND & $8.6^{\mathrm{fg}}$ \\
\hline $\mathrm{C}_{20}$ & $5.1 \mathrm{fg}$ & $8.8^{\mathrm{fg}}$ & $2.9^{\mathrm{ij}}$ & $9.2^{\mathrm{def}}$ & $0.9^{\mathrm{m}}$ & $10.7^{\mathrm{b}}$ & $\mathrm{ND}$ & $11.6^{\mathrm{a}}$ & $6.3^{\mathrm{e}}$ & $8.3^{\mathrm{gh}}$ & $3.9^{\mathrm{h}}$ & $9.1^{\text {ef }}$ & $1.6^{1}$ & $9.8^{\mathrm{cd}}$ & ND & $10.4^{\mathrm{bc}}$ \\
\hline \multicolumn{17}{|c|}{$\begin{array}{l}\text { Shoot } \mathrm{Zn} \text { and Cd } \\
\text { concentration }(\mathrm{mg}(\mathrm{kg} \\
\left.\text { DWl })^{-1}\right)\end{array}$} \\
\hline $\mathrm{C}_{0}$ & $20.1^{\mathrm{b}}$ & $6.8^{\mathrm{m}}$ & $14.1^{\mathrm{f}}$ & $7.9^{\mathrm{kl}}$ & $10.1^{\mathrm{k}}$ & $8.6^{\mathrm{ij}}$ & ND & $9.8^{\mathrm{fg}}$ & $24.6^{\mathrm{a}}$ & $4.3^{\circ}$ & $15.6^{\mathrm{d}}$ & $6.5^{\mathrm{m}}$ & $12.2^{\mathrm{h}}$ & $7.4^{1}$ & ND & $9.2^{\mathrm{h}}$ \\
\hline $\mathrm{C}_{10}$ & $15.6^{\mathrm{d}}$ & $7.9^{\mathrm{kl}}$ & $11.5^{\mathrm{i}}$ & $8.2^{\mathrm{jk}}$ & $9.1^{1}$ & $10.3^{\mathrm{ef}}$ & ND & $11.6^{\mathrm{C}}$ & $18.8^{\mathrm{C}}$ & $5.6^{\mathrm{n}}$ & $13.5^{\mathrm{g}}$ & $8.2^{\mathrm{jk}}$ & $10.0^{\mathrm{k}}$ & $9.1^{\mathrm{hi}}$ & $\mathrm{ND}$ & $10.8^{\mathrm{de}}$ \\
\hline \multicolumn{17}{|c|}{$\begin{array}{l}\text { Root Zn and Cd concentration } \\
\left(\mathrm{mg}(\mathrm{kg} \mathrm{DWl})^{-1}\right)\end{array}$} \\
\hline $\mathrm{c}_{0}$ & $52.1^{\mathrm{b}}$ & $10.0^{\mathrm{n}}$ & $40.5^{\mathrm{f}}$ & $12.1^{\mathrm{ij} k}$ & $30.0^{\mathrm{jk}}$ & $13.8^{\mathrm{efg}}$ & ND & $14.9^{\mathrm{cd}}$ & $56.4^{\mathrm{a}}$ & ${ }_{7.1} \mathrm{P}$ & $45.6^{\mathrm{d}}$ & $9.2^{\circ}$ & $34.8^{\mathrm{h}}$ & $10.8^{\mathrm{m}}$ & ND & ${ }^{11.6^{\mathrm{kl}}}$ \\
\hline$C_{10}$ & $42.6^{\mathrm{e}}$ & ${ }_{11 .} .^{\mathrm{j}}$ & $33.2^{\mathrm{i}}$ & $13.2^{\mathrm{gh}}$ & $25.7^{\mathrm{m}}$ & $14.4^{\mathrm{de}}$ & $\mathrm{ND}$ & $16.3^{\mathrm{b}}$ & $47.3^{c}$ & $9.4^{\mathrm{no}}$ & $40.6^{\mathrm{f}}$ & $12.3^{\mathrm{ij}}$ & $29.1^{\mathrm{kl}}$ & $13.6^{\mathrm{fg}}$ & ND & $15.2^{\mathrm{C}}$ \\
\hline $\mathrm{C}_{20}$ & $38.2^{\mathrm{g}}$ & $12.7^{\mathrm{hi}}$ & $28.3^{1}$ & $14.2^{\mathrm{ef}}$ & $19.7^{\circ}$ & $16.2^{\mathrm{b}}$ & ND & $17.9^{\mathrm{a}}$ & $40.6^{\mathrm{f}}$ & ${ }_{11.1}^{1 \mathrm{~m}}$ & $31.3^{j}$ & $13.3^{\mathrm{gh}}$ & $23.9^{\mathrm{n}}$ & $15.1^{d}$ & ND & $16.8^{\mathrm{b}}$ \\
\hline
\end{tabular}

its uptake by changes in soil structure, enhanced activity of microbes mobilizing $\mathrm{Zn}$ from tire rubber ash, or other processes that are not fully explained yet. Aghili et al. reported that application of organic amendments to $\mathrm{Zn}$ deficient soil can increase mycorrhizal activity and Zn uptake by plant. In addition, it has been reported that $\mathrm{N}$ content in organic amendment can increase microbial activity and thereby increase the concentration of some components such as organic acids that increase $\mathrm{Zn}$ mobilization in soil (25). Overall, N mediated effects on Zn uptake (33) and translocation in plants might be caused by the following mechanisms: (i) Stimulation of the release of Zn phyto-siderophores to the rhizosphere, (ii) stimulation of the synthesis of $\mathrm{Zn}$ transporter proteins expressed in the root epidermis and root hairs, and/or (iii) facilitation of intra-plant $\mathrm{Zn}$ re-mobilization from vegetative plant tissues to grains via stimulation of the synthesis of nitrogenous compounds. Enhanced plant growth and reduction of plant Cd concentration when canola grew in the presence of tire rubber ash enriched cow manure may also explain differences in GI value in different treatments.

\subsection{Conclusions}

The results of our study demonstrated that addition of tire rubber ash enriched cow manure to calcareous, Cd polluted, and $\mathrm{Zn}$ deficient soil is a viable strategy to biofortify canola with $\mathrm{Zn}$ and also reduces Cd concentration in canola grain. These findings are relevant to practice and thus, may help to implement locally available products (tire rubber ash and cow manure) into agricultural production. This in turn may be an important alternative to minimize $\mathrm{Zn}$ deficiency and Cd toxicity in the diet of people on the local scale. However, this research needs to be tested in the field location. On the other hand, the soil texture, the type of soil pollution, and plant physiology have important roles on plant heavy metal concentration. Therefore, the role of sorption properties of organic addition in decreasing Cd concentration can not be ignored.

\section{Acknowledgments}

The authors gratefully acknowledge the Islamic Azad University of Arak Branch for analyze samples.

\section{Footnotes}

Authors' Contribution: Amir Hossein Baghaie: Concept and design; Forough Aghili: Collection and analysis of data; Ali Hassani Joshaghani: Writing the manuscript and revision.

Conflict of Interests: Authors declared no conflict of interest.

Ethical Considerations: This research has not been a human or animal study.

Funding/Support: This research did not receive any specific grant from funding agencies in the public, commercial, or not-for-profit sectors.

\section{References}

1. Zhu G, Xiao H, Guo Q, Zhang Z, Zhao J, Yang D. Effects of cadmium stress on growth and amino acid metabolism in two 
compositae plants. Ecotoxicol Environ Saf. 2018;158:300-8. doi: 10.1016/j.ecoenv.2018.04.045. [PubMed: 29727812].

2. Jiang S, Weng B, Liu T, Su Y, Liu J, Lu H, et al. Response of phenolic metabolism to cadmium and phenanthrene and its influence on pollutant translocations in the mangrove plant Aegiceras corniculatum (L.) Blanco (Ac). Ecotoxicol Environ Saf. 2017;141:290-7. doi: 10.1016/j.ecoenv.2017.03.041. [PubMed: 28363172].

3. Liu X, Zhong L, Meng J, Wang F, Zhang J, Zhi Y, et al. A multi-medium chain modeling approach to estimate the cumulative effects of cadmium pollution on human health. Environ Pollut. 2018;239:308-17. doi: 10.1016/j.envpol.2018.04.033. [PubMed: 29665551].

4. Wiangkham N, Prapagdee B. Potential of Napier grass with cadmiumresistant bacterial inoculation on cadmium phytoremediation and its possibility to use as biomass fuel. Chemosphere. 2018;201:511-8. doi: 10.1016/j.chemosphere.2018.03.039. [PubMed: 29529578].

5. Shen Z, Hou D, Zhao B, Xu W, Ok YS, Bolan NS, et al. Stability of heavy metals in soil washing residue with and without biochar addition under accelerated ageing. Sci Total Environ. 2018;619-620:185-93. doi: 10.1016/j.scitotenv.2017.11.038. [PubMed: 29149742].

6. Khan MA, Khan S, Khan A, Alam M. Soil contamination with cadmium, consequences and remediation using organic amendments. Sci Total Environ. 2017;601-602:1591-605. doi: 10.1016/j.scitotenv.2017.06.030. [PubMed: 28609847].

7. Driessnack MK, Jamwal A, Niyogi S. Effects of chronic waterborne cadmium and zinc interactions on tissue-specific metal accumulation and reproduction in fathead minnow (Pimephales promelas). Ecotoxicol Environ Saf. 2017;140:65-75. doi: 10.1016/j.ecoenv.2017.02.023. [PubMed: 28235657].

8. Cheng Y, Wang C, Chai S, Shuai W, Sha L, Zhang H, et al. Ammonium $\mathrm{N}$ influences the uptakes, translocations, subcellular distributions and chemical forms of $\mathrm{Cd}$ and $\mathrm{Zn}$ to mediate the $\mathrm{Cd} / \mathrm{Zn}$ interactions in dwarf polish wheat (Triticum polonicum L.) seedlings. Chemosphere. 2018;193:1164-71. doi:10.1016/j.chemosphere.2017.11.058. [PubMed: 29874745].

9. De Oliveira VH, Tibbett $\mathrm{M}$. Tolerance, toxicity and transport of $\mathrm{Cd}$ and Zn in Populus trichocarpa. Environ Experiment Botany. 2018;155:281-92. doi: 10.1016/j.envexpbot.2018.07.011

10. Jiao Y, Chen J, Li W, Liu Y, Xin C, Yang L. Trace elements concentrations in squids consumed in Shandong Province China and their associated risks to the human health. Mar Pollut Bull. 2018;128:267-74. doi: 10.1016/j.marpolbul.2018.01.038. [PubMed: 29571373].

11. Dapkekar A, Deshpande P, Oak MD, Paknikar KM, Rajwade JM. Zinc use efficiency is enhanced in wheat through nanofertilization. Sci Rep. 2018;8(1):6832. doi: 10.1038/s41598-018-25247-5. [PubMed: 29717180]. [PubMed Central: PMC5931615].

12. Kumpiene J, Brannvall E, Wolters M, Skoglund N, Cirba S, Aksamitauskas VC. Phosphorus and cadmium availability in soil fertilized with biosolids and ashes. Chemosphere. 2016;151:124-32. doi: 10.1016/j.chemosphere.2016.02.069. [PubMed: 26933903].

13. Daneshbakhsh B, Khoshgoftarmanesh AH, Shariatmadari H, Cakmak I. Phytosiderophore release by wheat genotypes differing in zinc deficiency tolerance grown with $\mathrm{Zn}$-free nutrient solution as affected by salinity. J Plant Physiol. 2013;170(1):41-6. doi: 10.1016/j.jplph.2012.08.016. [PubMed: 23122914].

14. Rengel Z. Availability of $\mathrm{Mn}, \mathrm{Zn}$ and $\mathrm{Fe}$ in the rhizosphere. J Soil Sci Plant Nutr. 2015;15(2):397-409. doi: 10.4067/S071895162015005000036.

15. Ghiasi S, Khoshgoftarmanesh AH, Afyuni M, Chaney RL. Agronomic and economic efficiency of ground tire rubber and rubber ash used as zinc fertilizer sources for wheat. J Plant Nutr. 2016;39(10):1412-20.

16. Taheri S, Khoshgoftarmanesh AH, Shariatmadari H, Chaney RL. Kinetics of zinc release from ground tire rubber and rubber ash in a calcare- ous soil as alternatives to Zn fertilizers. Plant soil. 2011;341(1-2):89-97. doi:10.1007/s11104-010-0624-7.

17. Baghaie AH. [Effect of tire rubber ash enriched municipal waste compost on decreasing spinach Cd concentration (a case study: Arak municipal waste compost]. Iran J Health Environ. 2017;10(3):401-10. Persian.

18. Khoshgoftarmanesh AH, SanaeiOstovar A, Sadrarhami A, Chaney R Effect of tire rubber ash and zinc sulfate on yield and grain zinc and cadmium concentrations of different zinc-deficiency tolerance wheat cultivars under field conditions. Eur J Agron. 2013;49:42-9. doi 10.1016/j.eja.2013.02.013.

19. Soil Survey Staff S. Keys to soil taxonomy. Twelfth ed. United States Department of Agriculture: Pocahontas Press; 2014.

20. Baghaie AH. [Effect of municipal waste compost and zeolite on reduction of cadmium availability in a loamy soil (A case study: Arak municipal waste compost)].J Soil Manage and Sustain Product. 2017;6(4):10317. Persian. doi:10.22069/EJSMS.2017.10398.1616.

21. Nelson DW, Sommers LE. Total carbon, organic carbon, and organic matter 1. In: Weaver RW, Angle JS, Bottomly PS, editors. Methods of soil analysis. Part 2. Chemical and microbiological properties. 2. American Society of Agronomy, Soil Science Society of America;1982. p. 539-79.

22. Rhoades JD. Cation exchange capacity. In: Page AL, Miller RH, Keeney DR, editors. Methods of soil analysis. Madison, Wisconsin, USA;1982. p. 149-57.

23. Lindsay WL, Norvell WA. Development of a DTPA Soil test for Zinc, Iron Manganese, and Copper 1. Soil Sci Soc America J.1978;42(3):421-8.

24. Bremner JM. Nitrogen-total. In: Sparks DL, editor. Methods of soil analysis part 3-chemical methods. Soil Science Society of America, American Society of Agronomy; 1996. doi: 10.2136/sssabookser5.3.frontmatter.

25. Aghili F, Gamper HA, Eikenberg J, Khoshgoftarmanesh AH, Afyuni $\mathrm{M}$, Schulin R, et al. Green manure addition to soil increases grain zinc concentration in bread wheat. PLoS One. 2014;9(7). e101487. doi: 10.1371/journal.pone.0101487. [PubMed: 24999738]. [PubMed Central: PMC4084887].

26. Wilkins DA. The measurement of tolerance to edaphic factors by means of root growth. New Phytologist. 1978;80(3):623-33. doi: 10.1111/j.1469-8137.1978.tb01595.x.

27. Qaswar M, Hussain S, Rengel Z. Zinc fertilisation increases grain zinc and reduces grain lead and cadmium concentrations more in zincbiofortified than standard wheat cultivar. Sci Total Environ. 2017;605606:454-60. doi: 10.1016/j.scitotenv.2017.06.242. [PubMed: 28672234].

28. Sarwar N, Ishaq W, Farid G, Shaheen MR, Imran M, Geng M et al. Zinc-cadmium interactions: Impact on wheat physiology and mineral acquisition. Ecotox Environ Safe. 2015;122:528-36. doi: 10.1016/j.ecoenv.2015.09.011.

29. Farahani NT, Baghaie AH. [Interactive effect of $\mathrm{Fe}$ and $\mathrm{Pb}$ on decreasing corn $\mathrm{Pb}$ availability in a Pb-polluted soil]. J Water Soil. 2017;31(4):1187-99. Persian.

30. Chen Q, Lu X, Guo X, Pan Y, Yu B, Tang Z, et al. Differential responses to $\mathrm{Cd}$ stress induced by exogenous application of $\mathrm{Cu}, \mathrm{Zn}$ or $\mathrm{Ca}$ in the medicinal plant Catharanthus roseus. Ecotoxicol Environ Saf. 2018;157:266-75. doi: 10.1016/j.ecoenv.2018.03.055. [PubMed: 29626640].

31. De Oliveira $\mathrm{VH}$, Tibbett $\mathrm{M}$. Cd and $\mathrm{Zn}$ interactions and toxicity in ectomycorrhizal basidiomycetes in axenic culture. Peer J. 2018;6 e4478. doi: 10.7717/peerj.4478. [PubMed: 29568708]. [PubMed Central: PMC5845391].

32. Kabata-Pendias A. Trace elements in soils and plants. Fourth ed. Boca Raton, London, New York, Washington, D.C: CRC Press; 2010.

33. Kumar A, Bahadur I, Maurya BR, Raghuwanshi R, Meena VS, Singh DK, et al. Does a plant growth-promoting rhizobacteria enhance agricultural sustainability. J Pure Appl Microbiol. 2015;9(1):715-24. 